NBER WORKING PAPER SERIES

\title{
IMPLICATIONS OF THE CHANGING U.S. LABOR MARKET \\ FOR HIGHER EDUCATION
}

Richard B. Freeman

Working Paper No. $\underline{697}$

NATIONAL BUREAU OF ECONOMIC RESEARCH

1050 Massachusetts Avenue

Cambridge MA 02138

June 1981

This paper was prepared for the Leverhulme Programme of Study into the Future of Higher Education, Seminar on Higher Education and the Labor Market. The research reported here is part of the NBER's research program in Labor Studies. Any opinions expressed are those of the author and not those of the National Bureau of Economic Research. 
Implications of the Changing U.S. Labor Market for Higher Education

\section{$\underline{\text { ABSTRACT }}$}

This paper examines evidence regarding the impact of the changed labor market on the higher educational system. Four basic propositions can be drawn from the paper's findings.

Firstly, the labor market for the highly educated underwent a downturn in the 1970s, reducing the relative earnings of new college graduates and forcing them into jobs not normally considered as requiring college training. Secondly, this downturn resulted in a levelling off, and, in the case of white males, a sharp decline, in college enrollment. Statistical and survey questionnaire data show that this is due to the economic responsiveness of potential students to market incentives.

The effects of this labor market change were most severe in the liberal arts, teaching, and academic and research-oriented occupations. In other business-oriented fields such as management and accounting, and in engineering, economic opportunities remained substantial or in some cases improved. Consistent with these changes were changes in enrollments and degrees. Depressed job markets experienced rapid declines in enrollment, while fields such as engineering experienced an increase in enrollment. Concurrently, professional schools benefitted while liberal arts schools suffered from labor market induced patterns of change in enrollment.

Richard B. Freeman National Bureau of Economic Research 1050 Massachusetts Avenue Cambridge, MA 02138

(617) $868-3195$ 
The decade of the 1970s was one of significant change in the labor market for college-trained manpower. The once high and in some areas rising economic reward to college-going declined and many recent graduates found themselves with serious labor market problems. Newspaper and magazine articles turned attention to the unemployed teacher, the doctorate taxi driver, the college graduate employed in the factory. Throughout the society questions arose regarding the economic value of higher education, motivated such books as my Overeducated American (Academic Press, 1976).

The Burean of Labor Statistics, among others, forecast, significant, surplises of college graduates, in sharp contrast to traditional forecasts of shortages. State legislatures, federal agencies, students and their parents reacted to the new realities, placing academic institutions in a very different environment from the one they had enjoyed in previous decades. Rapid growth of higher education turned into stagnation and academic institutions were forced into modes of behavior quite different from those in previous periods of high demand for college education.

The purpose of this essay is to examine evidence regarding the impact of the changed labor market on the higher educational system. Special attention is given to late 1970 s developments that were not examined in early studies of the declining college job market. Section I reviews the pattern of change in the market for college trained workers. It seeks to determine the extent to which the dceline in the college job market has decelerated and the extent to which the graduates of the early seventies have recouped their economic position. Then it considers the way the market changes have altered the number of 
students seeking higher education. Section 2 turns to the questions of the impact of the market changes on the higher educational system. Section 3 summarizes our findings and evaluates the ways by which the higher educational system is adjusting to swings in the labor market.

I. What We Know (Or Think We Know) About the Changing Labor Market for College Educated Workers

A wide variety of evidence on the changing market for college educated workers has cumulated in the past few years. While there is some disagreement regarding interpretation of the evidence which I first analyzed in 2975 and 1976, developments in the latter part of the seventies appear to confirm the basic finding regarding the "turnaround" in the college job market that differentiated the decade from earlier post-World War II years. In this section, I review the most recent evidence of change in the college job market -- the experimental variation which enables us to probe the link between the labor market and higher education $-\rightarrow$ in order to assess the dimensions of changes. The most important findings which emerge from this analysis can be summarized in four basic propositions which constitute what we "know" about the changing labor market:

1) The labor market for the highly educated underwent a marked downturn in the decade which substantially reduced the relative earnings of new college graduates and which forced many into jobs not normally viewed as requiring college training. Measured as a rate of return, the return to four years of college fell from perhaps $11 \%$ to $7 \%$. While the decline in 
the economic opportunities for college workers decelerated or improved slightly at the end of the 1970s, there is no indication of a recovery of previous economic advantages by that time.

2) The downturn difterentially affected fielas, being nost, severe in liberal arts, teaching, academic and research oriented occupations. The downturn was more severe at the doctorate level than at other levels. By contrast, in certain business-oriented fields, such as managenent and accounting, in engineering, and in selected other specialities, economic opportunities remained substantial or in some cases improved contrary to the overall pattern.

3) There was a significant supply response to the market turnaround, with the proportion of young persons enrolling in college leveling off for some groups and actually falling sharply for white males. Both statistical and survey questionnaire data indicate that the changed enrollments reflect economic responsiveness of potential students to market incentives.

4) Consistent with the pattern of change in earnings and opportunities across fields, there was considerable variation in changes in enrollments and degrees. Fields with depressed job markets like teaching experienced rapid declines in enrollments while those with opposite markets like engineering had large increases in enroliments. Professional schools benefitted while arts and sciences suffered from the labor-market, induced patterns of change in enrollment. 
All told, the labor market for college-trained workers underwent extraordinary change in the 1970s, with significant implications for higher educational institutions.

I consider next the evidence for the four propositions, contrasting where relevant the patterns in the latter half of the decade with those in the 1969-75 period on which my earlier work focused.

\section{The Overall Decline}

The evidence that the labor market for the highly educated, especially new college graduates, underwent a major, unprecendented downturn in the 1970s is impressive. Statistics on incomes and starting pay show a marked deterioration in the economic status of graduates relative to other workers, while data on employment shows an increasing number of college graduates ending up in positions outside of traditional college-level job areas.

Table 1 summarizes data on the overall pattern of change in the earnings of college graduates. It compares several measures of the earnings of college graduates relative to the earnings of other workers from 1969, when the college marketplace was strong, to 1974 when it was substantially depressed and then to 1978 - 1980. To minimize the impact of cyclic changes on the comparisons, the data relate to the earnings of year-round full-time workers and actual monthly salary rates. Annual income figures which include the income of those without work for part of the year show similar patterns. The table shows a sizeable drop in the relative position of The highly educated during the period under study, especially among the young. From 1969 to 1974 the income of 25-34 year old male college graduates relative to 
Table 1: College to High School Income Ratios, 1969-81

$1969 \quad 1974 \quad 1978$

Income of Full-time Year Round Workers with Four Years of College to Income of Fu11-Time Year Round Workers With Four Years of High School
1. Men, 25-34
$\begin{array}{ll}1.39 \quad & 1.16^{\mathrm{a}} \\ & 1.20\end{array}$
$1.22^{\mathrm{a}}$
2. A11 Men
$1.53 \quad 1.35^{\mathrm{a}}$
1.36
$1.40^{\mathrm{a}}$
3. Women 25-34
$1.421 .29^{\mathrm{a}}$
$1.26^{\mathrm{a}}$
4. A11 Women
$1.361 .35^{\mathrm{a}}$

$$
1.28^{\mathrm{a}}
$$

Starting Salaries of College Men

Working in Industry to Average

Annual Earnings

5. Bachelor's

$1.24 \quad 1.09 \quad 1.05^{c}$

6. Doctorate

$2.18 \quad 1.78 \quad 1.87^{\mathrm{d}}$


in second row are based on new imputation procedure, as are figures for later years.

${ }^{b} 1980$ average annual earnings estimated from 1978 data in U.S. Statistical Abstract, 1980 , table 701 , by applying percentage change in hourly earnings in total private industry from Employment and Earnings, Jan. 1981, table c-1.

${ }^{c} 1979$.

$\mathrm{d}_{1981 .}$

Source: 1ines 1-4, Current Population Survey, Consumer Income Series P-60, various editions.

lines 5-6, Bachelor's from Endicott Report, various editions, using a reported average of salaries with weights .05 accounting, .35 engineering, .40 sales, .20, general business trainees. Doctorate, unweighted average from College Placement Council series. Earnings elsewhere, from U.S. Department of Commerce, Survey of Current Business, National Income editions. 
high school graduates dropped sharply, then rose modestly over the next four years, when the Current Population Survey underwent a modest change in methodology. For all men the pattern is similar, with an income ratio of 1.53 falling to 1.35 and then rising somewhat to 1.40 . For women, the pattern is quite different, but still evinces a declining advantage to the college trained. For 25-34 year olds there is a sharp drop from 1969 to 1974, followed by a slight decline thereafter whereas for all women income ratios are steady from 1969 to 1974 , but appear to fall in the latter part of the decade.

The pattern of falling relative income of college workers is also found in the ratio of starting salaries of graduates to average annual earnings shown in lines 5 and 6 of the table, which shows the bulk of the drop occurring in the early 1970s and some upturn in the latter part of the decade.

Overal1, we see that while there is some indication of a modest recovery in the college market from the severely depressed conditions of 1974, the recovery is insufficient to come even close to restoring the earlier income advantage of graduates. The market was depressed for graduate manpower throughout the decade following the heralded turnaround.

Parallel to the drop in the relative income of college students was a deterioration in employment opportunities. This deterioration forced an unprecedented number of college graduates, particularly those starting their careers, into non jobs. Also jobs outside their area of study, or into unemployment.

Table 2 examines this aspect of the changing college job market. It compares the types of jobs and difficulties in obtaining positions in 1969 with the situation in 1975 and in 1979. Lines $I$ and 2, which give the most comprehensive statistics on the employment of graduates, show that the proportion 
Table 2: Measures of the Employment Opportunities of College Workers 1969-1979

$1969 \quad \underline{1975} \quad \underline{1979} \Delta$ in Percentage Points

1. Proportion of Workers With

4 or More Years of College

in Professional Jobs

Males

.61

.54

.52

$-.09$

2. Proportion of Workers with

4 or More Years College

in Professional Jobs

Females

.81

.70

.65

$-.16$

$\underline{1962-68} \quad \underline{1969-76} \quad \underline{1976-79}$

3. Ratio of Additional College Graduates in Professional Jobs to Additional College Graduates

Source

Line 1,2, U.S. Department of Labor, Educational Attainment of Workers March 1969 (Special Labor Force Report 125, Table I, p. A-28) and Special Labor Force Report 186, table I, p. A-19, and Special Labor Force Report 240, table 5, p. A-19).

Line 3, U.S. National Center for Education Statistics, Condition of Education 1979, table 1.11, updated 
employed in the traditional occupational area of the college-educated, the professions, fell sharply in the period, by 9 percentage points for men and 16 percentage points for women.

The data on employment of college graduates is organized in line 3 in a different fashion to focus on the likely occupations of the new cohorts of graduates. From 1962 to 1968, the number of college graduates in the labor force grew by 4,017,000. The number obtaining professional jobs grew by 2,9.15,000 - implying that 73\% of the additional college workers got professional employment. From 1969 to 1976, by contrast, when the number of graduates grew by 8,096,000, the number obtaining professional jobs grew by just 3,751,000 - a $46 \%$ rate of increased ermployment in the professions. From 1976 to 1979, the number of graduates increased by $3,706,208$, while the number working as professionals increased by $1,627,000$ - a $44 \%$ rate of increased employment in the professions. As in earlier calculations, we find a dramatic change from the 1960 s to the 1970s, with the rate of deterioration lessening; in this case, leveling off in the late 1970s.

\section{Rates of Return}

The decline in the economic position of college workers in the 1970s was accompanied by continued rises in the direct cost of education, with the necessary consequence that the rate of return to investment in college fell. Table 3 compares costs of training with the income rewards accruing to young (25 to 34 year old) male graduates. For historic perspective, the table covers a longer period than tables 1 and 2; for comparability of incomes over time, it deals with income of all workers rather than year-round full-time workers. 
Table 3: Changes in the Cost of College and in the Ratio of Costs to the Benefits of College, 1949-78

(a11 in 1967 constant \$)

$1949 \quad \underline{1961} \quad \underline{1969} \quad \underline{1974} \quad \underline{1978} \quad \underline{\% \Delta 69-78}$

1. Cost of Higher Education

$\begin{array}{lrrrrrr}\text { a. Tuition \& Fees, } & 153 & 248 & 295 & 341 & 284 & -3.8 \\ \begin{array}{l}\text { public } \\ \text { b. Tuition \& Fees, }\end{array} \quad 655 & 1011 & 1397 & 1550 & 1429 & 2.3 \\ \quad \begin{array}{l}\text { private } \\ \text { c. Total cost/pupil }\end{array} \quad 1182 & 1995 & 2686 & 3411 & 2628 & -2.2 \\ \quad \begin{array}{l}\text { (current-fund } \\ \quad \text { expends/degree- } \\ \text { credit enroll- } \\ \text { ments }\end{array} & & & & & & \\ \end{array}$

2. Earnings of men $25-34$

$\begin{array}{lllllll}\text { a. college grad } & 5773 & 8334 & 9815 & 8350 & 8364^{\mathrm{a}} & -14.8 \\ \text { b. high school } & 4546 & 5979 & 7407 & 7267 & 6925^{\mathrm{a}} & -6.5 \\ \text { c. difference } & 1227 & 2365 & 2708 & 1083 & 1440 & -40.0\end{array}$

${ }^{a}$ Adjusted for comparability with earlier surveys using figures in Freeman, 1978, table 1 .

line 1a-b, 1969, 1974 from U.S. Office of Education, Projections of Educational Statistics to $1984-85,1975$ ed., p. 106.

1961, from U.S. Office of Education, Projections of Educational Statistics

to 1978-79, 1969 ed., Table 50, p. 107.

1949, from National Science Foundation, Statistical Handbook of Science

and Education, (NSF 60-13), Figure 48, p. 51.

line 1c, U.S. Office of Education, Digest of Educational Statistics, 1975, table 92, obtained by dividing current fund expenditures by resident degree credit enrollment, updated with data from Digest of Educational Statistics, 1980.

line 2, U.S. Bureau of the Census, Current Population Reports Consumer Income Series P-60 No. 92, Table 1 with ungrouped data adjusted by ratio of ungrouped means in 1967. No. 75, Tables 47, 58, and 101. No. 123, Table 50.

U.S. Dept. of Commerce, Trends in the Income of Families and Persons in the U.S., technical paper 8 , Table 3 .

1949 earnings from H.P. Miller, "Annual and Lifetime Income in Relation to Education: 1939-1959," AER, (Dec. 1960) Table 1. 
Line 1 shows a rough stability/modest increase in the real cost of college in the 1970s, with tuition and fees in public colleges falling by $4 \%$, tuition and fees in private institutions rising by $2 \%$ and total cost per pupil decreasing by $2 \%$ in the $1969-78$ period. Line 2 turns to the benefit side of the picture. It records the difference between the income of college and high school graduates. Consistent with the picture in table 1 , the data reveal a marked drop in the absolute real differential between young male college and high school workers in the period. Whereas in 1969, 25-34 year old college men earned $\$ 2408$ more than similarly aged high school graduates, in 1978, their advantage was just $\$ 1440$, a striking 40 percent decline. Note, however, that in these comparisons as in the others, the bulk of declines occurred in the early part of the decade, with the position of young male college graduates improving somewhat after the mid-1970s.

The way in which these changes affect rates of return depend on assumptions about future income profiles. If the college graduates of 1970 s are on permanently lower trajectories than has traditionally been the case, the return to their investment will be lower than if they manage to recoup at least some of the relative income losses of the period. In their critique of mr analysis, Welch and Smith argued that college graduates are, in fact, likely to make some relative gains in the future, which implies that the analyses based on starting salaries of the earnings of young college graduates exaggerate the magnitude of changes. Sufficient time has progressed to allow for some evaluation of this possibility. To what extent, if any, have the graduates of the early seventies experienced especially rapid rates of growth in earnings, which would enable them to recoup traditional college earnings differentials over the life cycle? 
Three studies have dealt with this question, yielding consistent and definite results. One, by Marc Meyer, has found that college graduates in the National Longitudinal Survey ("Parnes" data set) had slower rather than faster rates of increase in salaries over the period. A second, by Donovan and Raisan, found that in the Michigan Panel Survey of Income Dynamics college graduates had slower rates of growth by about $1 \frac{1}{2}$ percentage points per year than high school graduates but that the rates of growth grew closer together toward the latter seventies. My own work, comparing cohorts in the Current Population Survey also finds slower growth in the earnings of college men over the period. All of these studies suggest that, if anything, the diminution in the advantage of young college graduates shown in tables 1 and 3 understates the possible lifetime income loss of the seventies graduates. While the evidence suggests that the bulk of the turnaround has occurred, it does not support the notion that the seventies graduates are recouping their economic loss over the lifecycle. We conclude that the developments of the 1970 s have caused a real economic 1oss.

\section{Variation Among Fields}

One of the basic features of the declining college market of the 1970s has been the vastly different experience of diverse fields and degrees. Generally speaking, the pattern has been of exceptional decline in academic and research fields in contrast to more modest decline or increases in businessoriented occupations like business, engineering, and medicine.

Table 4 documents the differential pattern of change in salaries. The figures on bachelor's starting rates show sizeable variation in the rate of decline in the real starting pay of college men from 1969 to 1975 and from 
Tab1e 4: Average Month1y Salary offers to College Graduates from Business

Bachelor's

\begin{tabular}{|c|c|c|c|}
\hline urrent & Dollar & Salaries ${ }^{b}$ & $\begin{array}{l}\text { Percentage Change } \\
\text { in Constant } 1967 \$^{c}\end{array}$ \\
\hline 96 & $1974-5$ & $1980-81$ & $75-81$ \\
\hline
\end{tabular}

Business:

Accounting

Genera1

836

721

980

847

1413

1329

$-16$

$-15$

$-11$

864

1116

1880

$-7$

$-4$

Engineering ${ }^{a}$

700

781

1144

$-20$

3

umanities and

Social Sciences

825

962

1572

$-16$

$-11$

Chemistry

794

924

1574

$-16$

0

Mathematics

977

1664

$-$

4

Computer Science

$-$

$\underline{\text { Master's }}$

MBA (after non-

1044

1250

1906

$-14$

$-7$

technical under-

graduate degree)

Engineering ${ }^{a}$

1007

1246

2072

$-11$

1

Chemistry

978

1118

2028

$-16$

11

Mathematics

959

1138

1828

$-15$

$-2$

Computer Science

1169

1981

3

Doctorate

Engineering ${ }^{a}$

Chemistry

Mathematics
1353

1278

1421
1550

1503

1523
2639

2393

2446
$-18$

$-15$

$-23$
4

$-3$

$-2$

${ }^{a}$ Unweighted average of a11 fields

$\mathrm{b}_{1969-70}$ and 1974-75 figures for BAs relate to males; 1980-81 figures relat to men and women. 1969-70 figures for Master's and Doctorates relate to men; later figures relate to men and women.

Deflator 1969-70 116.3

1974-75 161.2

$1980-81 \quad 264.9$

Source: Digest of Educationa1 Statistics 1972, p. 144, table 153-154. The Condition of Education 1979, p. 208, table 5.17. CPS Salary Survey, March 1981. Digest of Educational Statistics, 1978, p. 179. 
1975 to 1980 . Humanities and social science majors experience a loss in rea 1 starting; pay of 20 percent in the first period and of $11 \%$ in the second period. Accountants and general business graduates did somewhat less poorly, while chemists and mathematicians have smaller rates of decline and hold their own or gain in the '75-'81 period. Engineers do the best, particularly in the latter part of the decade. As a result of the changes in 1969, the ratio of the starting pay of B.S. engineers to that of bachelor's humanities and social science majors was 1.23 ; in 1981 , it was 1.64 !

The rates of change for $\mathrm{Ph} . \mathrm{D} . \mathrm{s}$ and master's graduates tell a similar story about the locus of the decline by the degree level and field. On average, from 1969 to 1980, Ph.D. and Master's starting pay fell by nearly 20\%. Within the same field, the salary of doctorate and masters personnel declines more rapidly than that of bachelor's graduates, save for MBAs, where the rates of change were similar. The especially large drop in the real pay of $\mathrm{Ph} . \mathrm{D}$. and MA or MS workers significantly cut their premium over bachelor's graduates and thus lowered the rate of return to postgraduate training. In 1969, a Ph.D. engineer earned 57 percent and a MS engineer 17 percent more than a B.S. engineer in the specialty. In 1980, the advantage to the Ph.D. or MS had fallen to 40 percent and 10 percent respectively. Across fields engineering and to a lesser extent chemistry did relatively well toward the end of the decade.

Finally, information on the types of jobs obtained and difficulties in finding positions by field of study tell a similar story about patterns of change across fields. According to the surveys of the National Education Association, elementary and high school teaching was one of the most depressed fields, with the proportion of new education graduates obtaining teaching jobs dropping from 74 percent in 1962 to 48 percent in 1974 (see N.E.A., 1977). In February 1978, when 5.9\% of all 1976-77 bachelor's recipients were unemployed, the rate for arts and science graduates stood at $7.9 \%$, with a $9.5 \%$ rate for humanities majors and $11.4 \%$ rate 
for B.S. biological scientists (National Center for Educational Statistics, Condition of Education, 1979).

The drastically different markets for various disciplines has not escaped the attention of college placement officers, who note," "... what's bad is getting worse... in general the market in technical areas has been the best that it's been in years... (whereas) for the kid coming out of a general studies background the market is flat". In spring 1981 the New York Times summarized the pattern:

"Engineers are being hungrily wooed with salary offers reaching $\$ 30,000$ a year, while liberal arts majors are scraping to find openings that pay $\$ 12,000 . "$ We conclude that the downturn in the college marketplace was substantially concentrated in certain areas and in certain types of degrees, as opposed to others.

\section{Enrollnent Response}

The impact of the changing labor market for college graduates on the higher educational system depend in large part on the supply responsiveness of young persons to the decline in incentives. Figure $I$ presents data on the enrollment behavior of young persons in the changing college market. It depicts the proportion of 18 to 19 year olds enrolled in college from 1951 to 1979 and the percentage from specific high school graduating classes enrolled as freshmen in the following year. What stands out in the data is the sudden sharp fall in the relative number of male college students, which began in 1969 (1968 in the high school graduate data), when the labor market turned down after more than a decade of substantial increases. In $1969,44.0$ percent of 18 to 19 year old male civilians enrolled in college, and 60 percent of new high school male graduates elected to become freshmen (down from 63 percent in 1968). Five years later, just 33.4 percent of 18 to 19 year old males and 49 percent of male high school graduates went on to college - remarkable declines of 10.6 and 11 percentage points. Ten years later, the figures are similar, 33.3\% of 18 to 19 year 
Figure 1: Proportion of Young Men and Wonen Enrolled in College

$$
1951-1979
$$

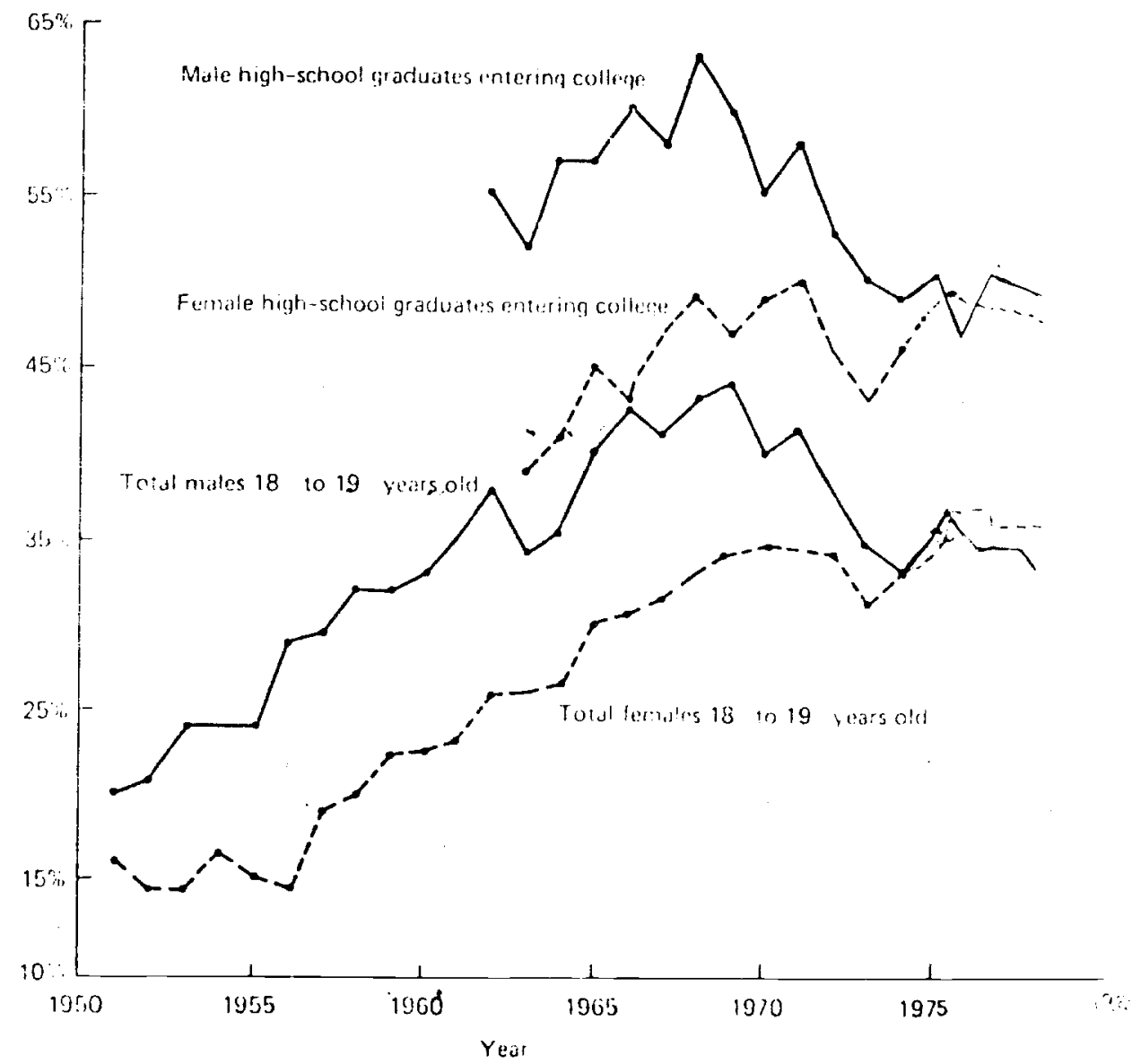

Source: U.S. Bureau of the Census, "School Enrollment," Current Population Reports, Series P-20; various editions, 1950-197\$; U.S. Bureau of Labor Statistics, Employment of High School Graduates and Dropouts, Special Labor Force Reports. 
old males enrolled in college and 50\% of male high school graduates entered college. Consistent with our findings about the time pattern of change in relative earnings and employment, the bulk of the drop in the enrollment proportions occurred in the first half of the decade, stabilizing thereafter.

Among women, figure I shows a somewhat different story. Here, enroliment rates level off in the 1970s but do not decline. In $1969,34.4$ percent of women aged 18 to 19 entrolled in college; in 1974, 33 percent and in 1979, 36 percent. The proportion of female high school graduates going on to college remained roughly stable over the same period (47 percent in 1969, 46 percent in 1974 and 48 percent in 1979). As a result of the decreasing proportion of young men going on to college and the stability in the proportion of young women, the female share of entering students rose sharply in the period. In 1979, women constituted 52 percent of 18 to 19 year olds in college compared to 46 percent of 18 to 19 year olds in 1969. The stability in female college enrollment compared to the drop in male enrollments is, it should be noted, consistent with the data on relative economic rewards which suggested that the payoff to female college-going did not decline as quickly or consistently as that for male collegegoing in the seventies.

Was the decline in the proportion of young persons going to college concentrated among persons from less advantaged backgrounds or did it occur more evenly among those from high as well as low or middle income families? Surprisingly, perhaps, U.S. Bureau of Census evidence shows relatively little decline in college-going among persons from very low family income and roughly comparable declines among those from families above the lowest level: 
Percentage Enrolled of Dependent Family Members, 18 - 24

$\begin{array}{rrrr}\text { Family Income } & \text { \% Enrolled } & \text { Family Income } & \text { \% Enrolled } \\ 0-2,999 & 13.7 & 0-4,999 & 12.1 \\ 3-4,999 & 19.6 & 5-9,999 & 14.7 \\ 5-6,999 & 29.5 & 10-14,999 & 16.1 \\ 7-9,999 & 37.4 & 15-19,999 & 22.7 \\ 10-14,999 & 45.7 & 20-24,999 & 28.2 \\ 15,000+ & 59.8 & 25,000+ & 46.0\end{array}$

Source: U.S. Bureau of Census, Current Population Report, Series P-20, No. 222, Figure 1, No. 360, Table 13.

The fali in enrollments from the middle and upper classes represents a major change in the traditional pattern of intergenerational mobility: for the first time, large numbers of young persons appeared likely to obtain less schooling and potentially lower occupational status than their parents.

At the graduate level, the drop in the proportion of young persons from the relevant supply group - those with college degrees - choosing to enroll for graduate work had fallen equally sharply. This development is examined in Table 5, which present two sets of figures on graduate enrollments--Office of Education data, based on surveys of institutions of higher education, and Bureau of the Census data, which are obtained from the Current Population Survey of individuals. Lines 1 and 2 record the absolute number enrolled in graduate programs in 1969, when the market was still strong and in 1975, after several years of downturn. Line 3 gives estimates of the relevant population which could be expected to go on to graduate studies: college graduates aged 22 to 29 while lines 4 and 5 present the estimated "propensity to enroll for graduate work," defined as the ratio of the figures in lines 1 and 2 to those in line 3 . According to the statistics, the absolute numbers pursuing graduate work increased moderately from 1969 to 1975, but much less rapidly than did the relevant population of eligibles, substantially reducing the proportion enrolled. From 1975 to 1979, the rate of enrollment appears to have levelled off. For 
Table 5: Changes in the Proportions of Persons Going for Graduate Education

\begin{tabular}{|c|c|c|c|c|c|c|}
\hline & & 1969 & 1975 & 1979 & $\% \Delta, \quad 69-79$ & $\% \Delta, 75-79$ \\
\hline 1 . & $\begin{array}{l}\text { Number enrolled } \\
\text { for graduate work } \\
\text { (O.E.)(in '000's) }\end{array}$ & 955 & 1263 & 1457 & 32.2 & 5.4 \\
\hline 1. & $\begin{array}{l}\text { Number enrolled } \\
\text { for } 5 \text { or more years } \\
\text { (census) }\end{array}$ & 1138 & 1590 & 1691 & 39.6 & 6.4 \\
\hline 3 . & $\begin{array}{l}\text { Number of } 22-29 \text { year } \\
\text { olds with } 4 \text { years } \\
\text { of college }\end{array}$ & 2281 & 3932 & 4280 & 72.4 & 8.8 \\
\hline 4. & $(1) /(3)$ & 41.9 & 32.1 & 34.0 & -23.4 & 5.9 \\
\hline 5. & $(2) /(3)$ & 49.9 & 40.4 & 39.5 & -19.0 & -2.2 \\
\hline
\end{tabular}

Source: 1ine 1, National Center for Education Statis, Projections of Education Statistics to 1986-8, table 9 (1979 an estimated figure)

1ine 2, U.S. Bureau of the Census, Current Population Reports, Series P-20, \#206, \#303, \#360, Table 3 .

1ine 3, Series P-20, 非194, 非95, 非56, Table 1 . 
1979 the Office of Education data show 34\% of 22 to 29 year old graduates were enrolled in graduate/professional schools compared to $42 \%$ a decade earlier, while the Bureau of Census data show $40 \%$ enrolled compared to $50 \%$ a decade earlier.

\section{Interpretation}

An economist finds it natural to link the changes in the job market documented under proposition 1 with the observed changes in enrollments examined here in terms of the labor supply behavior of potential students and their families. Two very different types of evidence support this interpretation. First, survey evidence on the reasons young people give for going to college find earnings on job opportunities high on the list, which suggests considerable supply responsiveness. Nearly 80 percent of freshmen surveyed by the American Council of Education in 1977 agreed, for example, that a major reason for going to college was that it would enable them to get a better job. Nearly one-third cited "able to make more money" as a very important reason for going to college. Similar results are obtained with questions relating to choice of career. Second, econometric analysis indicates that the income of graduates relative to other workers and/or measures of relative employment opportunities does a good job in tracking actual patterns of enrollment over time. Most other factors which might be cited as explanations of the observed changes - such as the draft, cyclical unemployment, inflationary cuts in real family income, do not account for the observed changes.

How important are changes in the prepensity of students to enroll in college due, it appears, to economic incentives in the changing number going to college? Despite the great emphasis placed in recent discussion of enrollment on demographic developments, market-induced changes in the proportion choosing to enrollment have been extremely important. For example, from 1970 to 1979 enrollment of men aged 
18-19 in college fell by 5,000 whereas the 18-19 year old male population increased by 843,000 (Bureau of the Census, Series P-20). The dominant factor in the change was the change in propensity to enroll, not the change in the size of the population. While the importance of changes in enrollment propensities in altering flows of students will vary with market conditions, group and time period, it is apparent that one of the critical aspects of the labor market--higher education linkage is the supply responsiveness of the young.

\section{Field Variation}

There is a sizeable body of evidence supporting proposition 4--that the changing market place for college workers affects not only the overall decision to enroll but also the field of study chosen. In the 1970 s the differential change in the income and employment conditions in the various college-level occupations appears to have generated a significant supply response from young persons in the process of choosing their careers. As would be expected of economically responsive decision-makers, students shifted from fields facing the worst market conditions to those with relatively better prospects.

Table 6 documents the overall pattern of change in the career plans of of entering freshmen. What stands out in the table is the remarkable shift of both men and women from academic to business-oriented fields, which would be expected if students were responding to the differential incentives described earlier. Whereas in $1966,2.1 \%$ of men and $1.5 \%$ of women planned to teach in colleges and $11.3 \%$ of men and $34.1 \%$ of women planned to teach in elementary and secondary school, in 1979, just $0.3 \%$ of male freshmen and $0.2 \%$ of females intended on college teaching and just $2.7 \%$ (male) and $10.4 \%$ (female) considered elementary or secondary school teaching. The proportion of both groups intending business careers rose over the entire period, by nearly sevenfold among women; while the proportion of men intending to enter engineering fell from 1966 to 1974, then jumped from 1974 to 1979. 
Table 6: Distribution of Freshmen by Probable Career Occupations

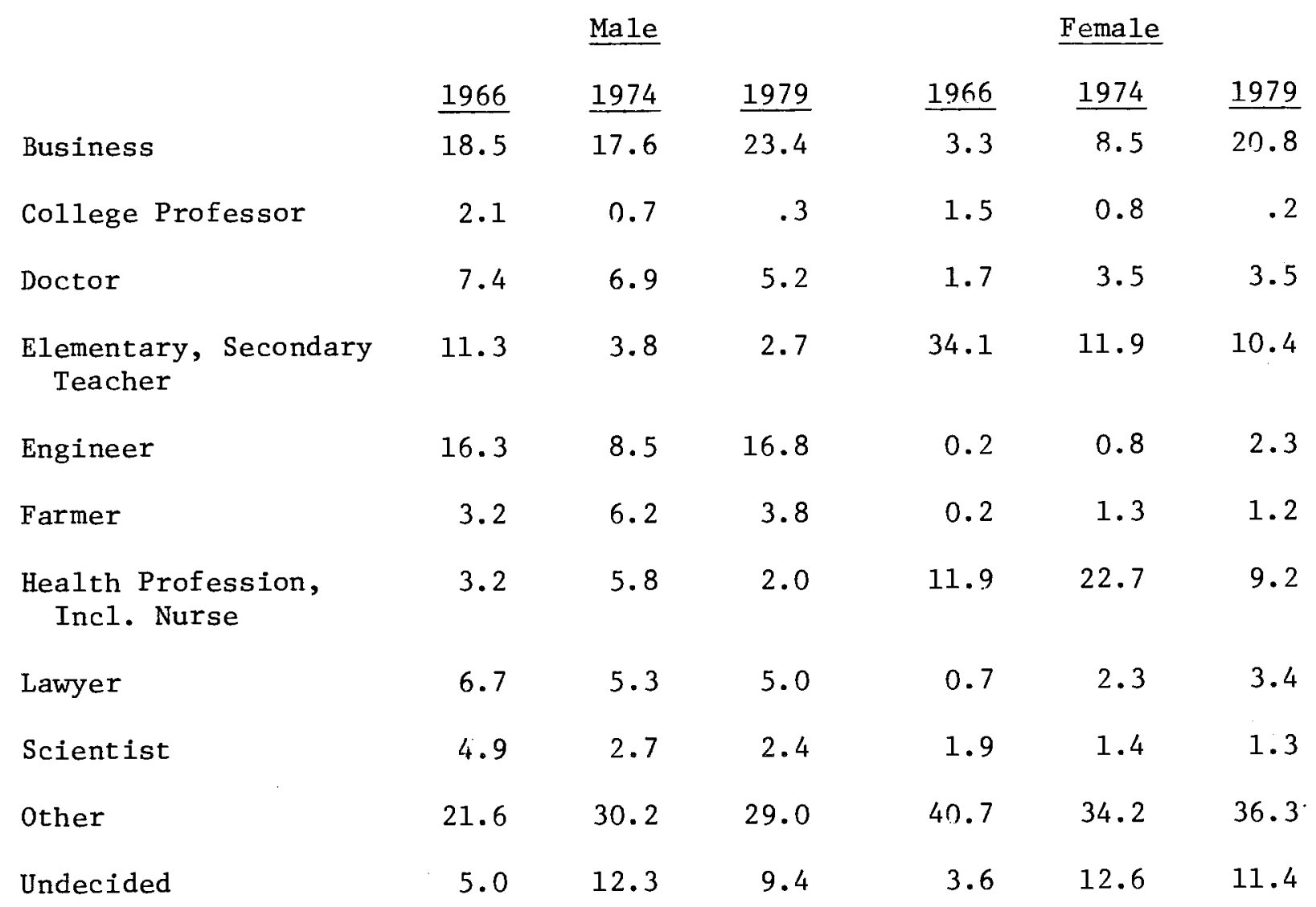

Source: American Council on Education,

The American Freshmen: National Norms for Fall 1974, 1979

National Norms for Entering College Freshmen, Fall 1966 
The enrollment and degree data in figure 2 provides

further evidence of the striking changes experienced by diverse fields in the period:

-In the hard hit education area, the number of bachelor's degrees fell by 19 percent in the 1970-1978 period.

-In physics, whose job market turned down earlier than in other fields, despite a two-fold increase in the total student body, junior and senior majors declined from 14,900 (1961) to 10,900 (1971) and first year graduate enrollments by over one half.

-In fields with stronger job markets, life sciences, agriculture and business-oriented specialties, by contrast, degrees increased. The number of MBA's, for example, grew greatly from 1970 to 1978.

-Perhaps most impressive in terms of the differential pattern of changes among fields is the experience of engineering, which throughout the late 1960 s and early 1970 s had substantially declining enrollments. From 1973 to 1979, first year enrollments in B.S. engineering, which had in 1973 plummetted to its lowest figure since 1949, despite the expansion of higher education, rose by about 50,000 in accord with the cobweb dynamics that seem to characterize that field.

Econometric evidence relating the number of students enrolled or graduating in various fields to salaries in those disciplines and to salaries in alternative professions confirm the economic responsiveness interpretation of the patterns. While precise estimates depend on the specification of models, years covered, and measures of variables, the general finding is that salaries have a significant and large impact on supply decisions. Table 8 summarizes some of the relevant estimates of elasticities for particular fields and for all freshmen in college. Column 1 gives estimates of the "short run" effect of salaries, where short run relates to the response in a given year. Column 2 gives estimated "long run" elasticities, generally calculated from a partial adjust- 
Figure 2
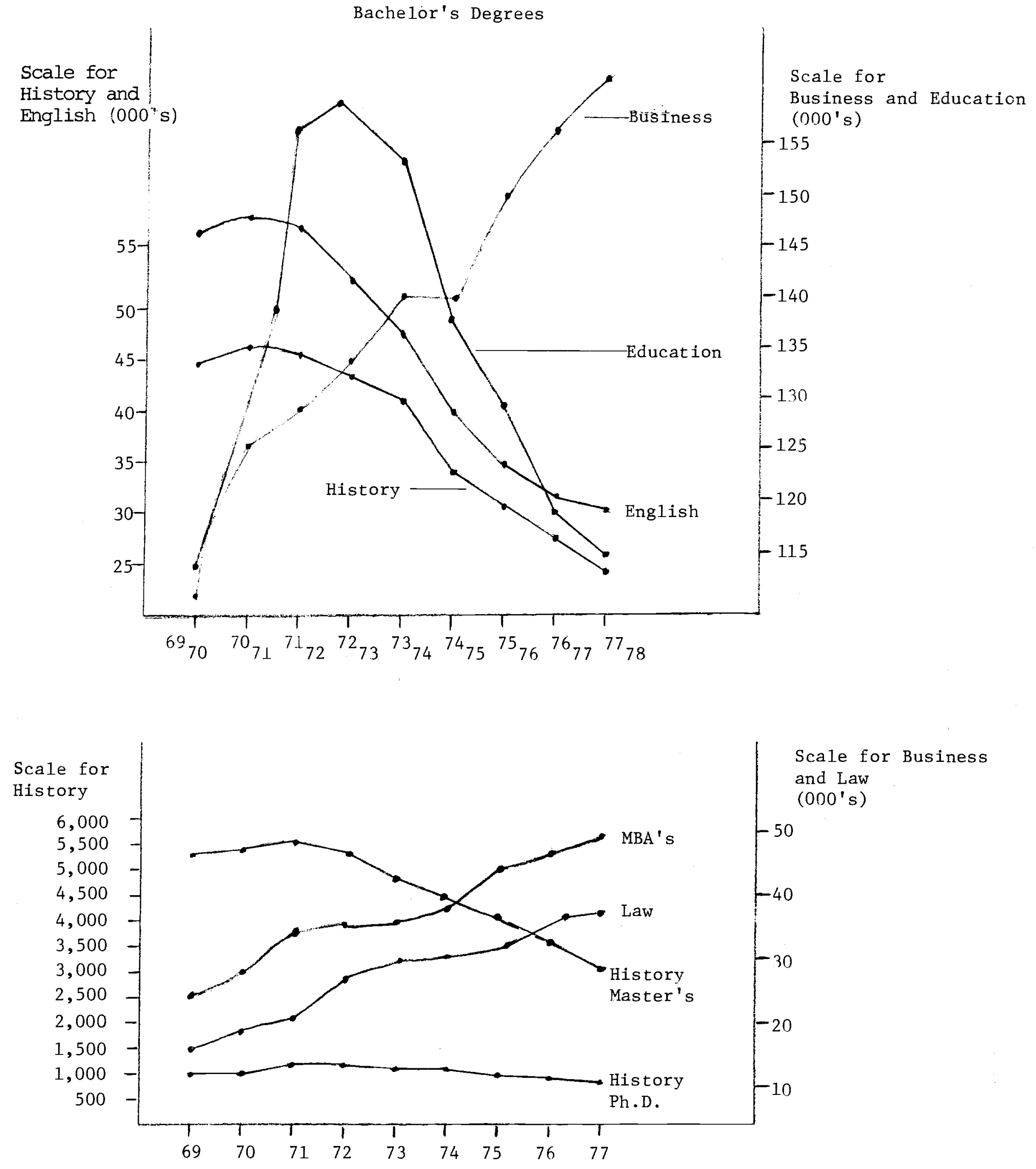

Master's Degrees

Source: National Center for Educational Statistics 
Figure 2:
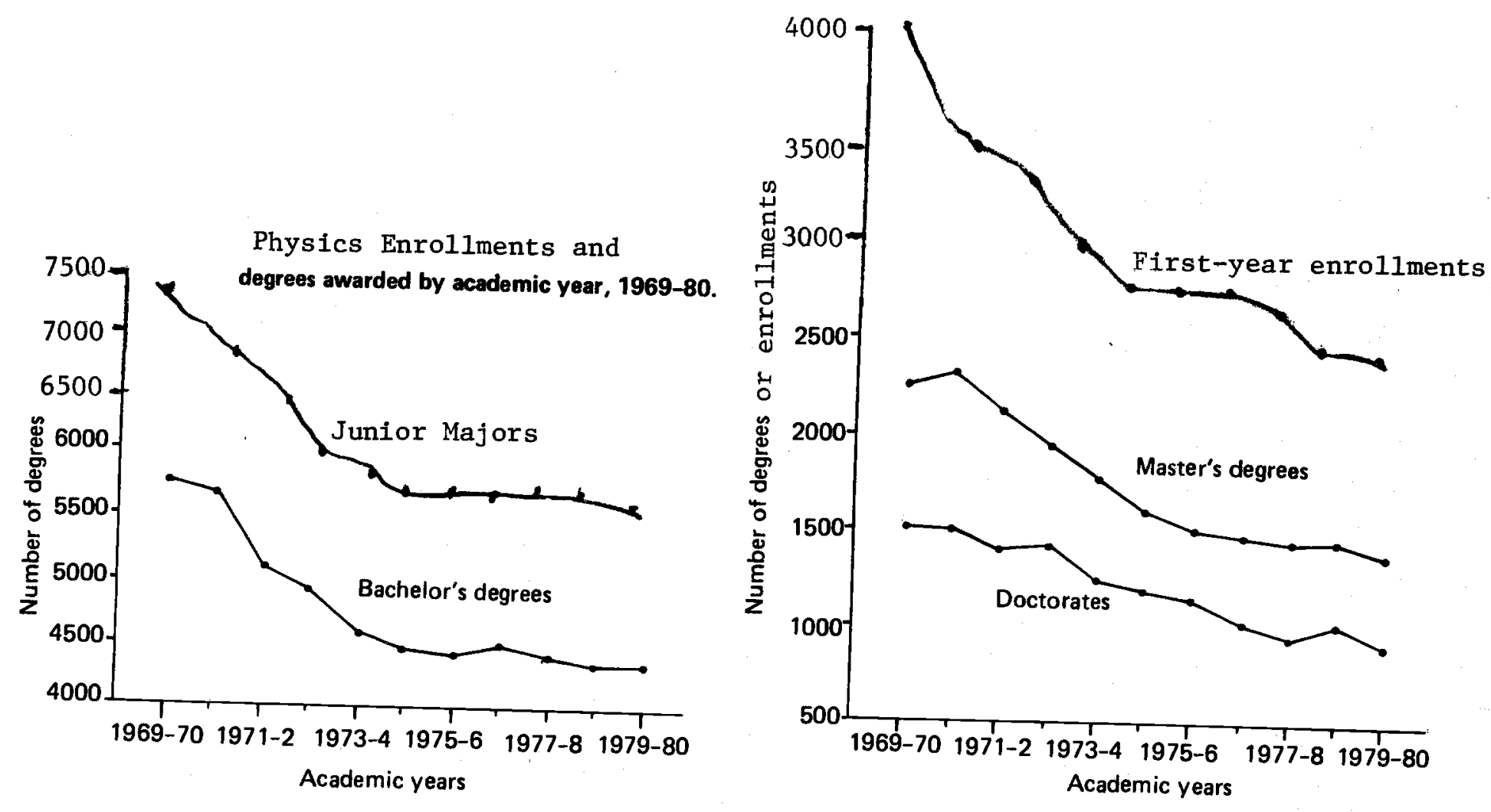

Source: American Institute of Physics 
Figure 2

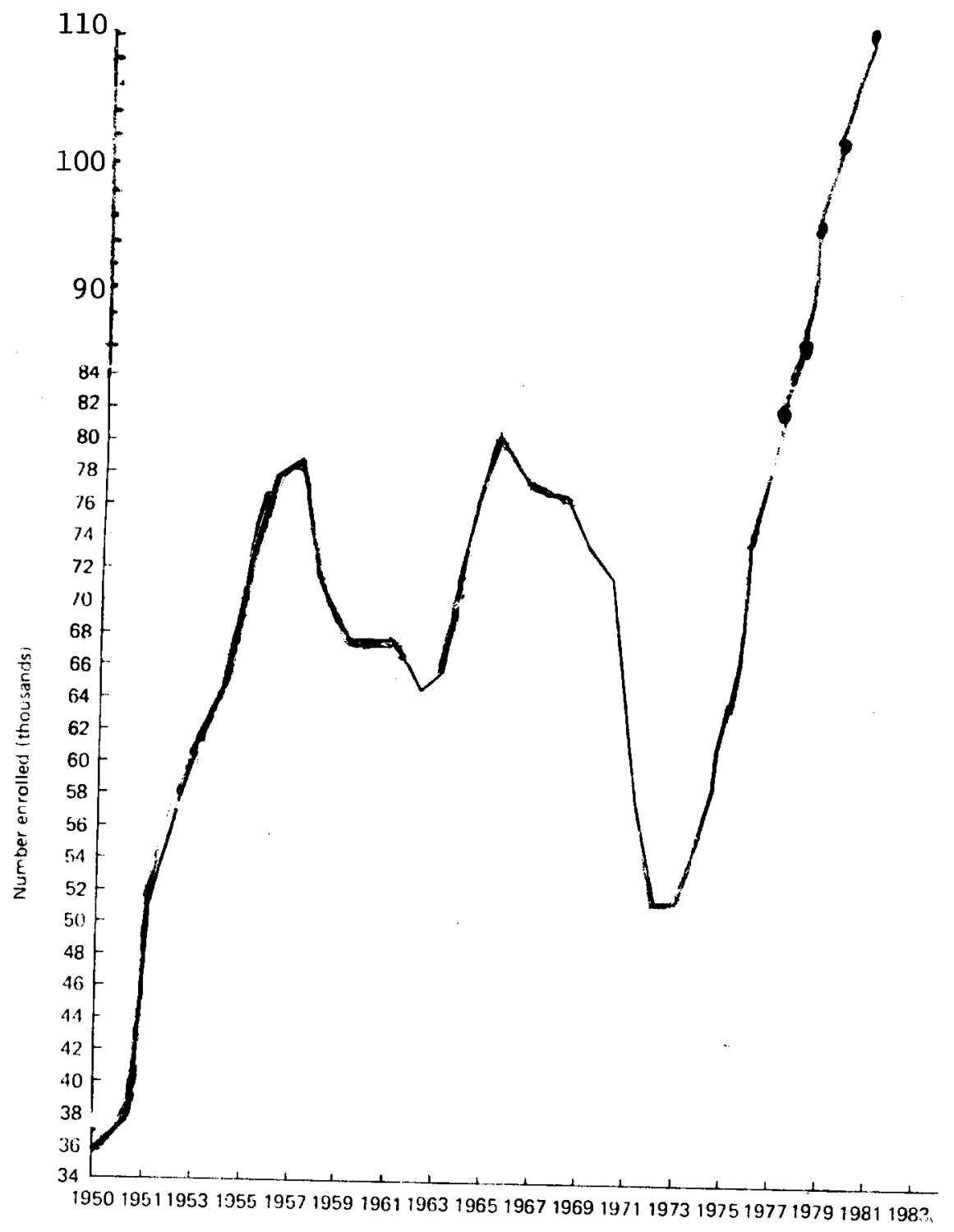

First Year Enrollments in Engineering

Source: American Association of Engineering Societies 
ment model. Because the models and parameter estimates are crude and subject to change given more detailed specification or new observations, the calculations are to be viewed as providing orders of magnitude of the behavioral relations. The elasticities for specific fields range from 1 to 2 in the short run and from 3 to 4 in the long run.

Even more striking, perhaps, is the remarkable difference in the accuracy of projections of future degrees in fields based on supply responsive behavior and projections based on traditional trend forecasts. As indicated below, in the case of physics forecasts based on economic responsiveness predicted not only the decline in PhDs granted in physics, while trend forecasts predicted increases, but came within $10 \%$ or so of the actual number granted, after allowances for increased numbers of foreign students whose behavior would reflect opportunities in their country and other factors unrelated to the state of the U.S. market for physicists.

$\begin{array}{ccccccc}\text { actual } & \begin{array}{c}\text { actual } \\ \text { adjusted } \\ \text { for foreign } \\ \text { students }\end{array} & \begin{array}{c}\text { supply } \\ \text { response } \\ \text { model }\end{array} & \begin{array}{c}\text { Trend Forecasts } \\ \text { Office of } \\ \text { Education }\end{array} & \text { Cartter } & \text { NAS-NRC } \\ 1969-70 & 1500 & 1500 & 1500 & 1500 & 1500 & 1500 \\ 1974-75 & 1133 & 1133 & 1189 & 2153 & 1853 & 2153 \\ 1979-80 & 885 & 843 & 786 & 2492 & 2654 & 3350\end{array}$

Source: See Freeman (1975). Actual from American Institute of Physics; Adjusted for increases in forcign students from $13 \%$ of Physics Phis to $25 \%$ from 1970 to 1975 and 1900 reported by National Rescarch Council.

All told, the evidence on incomes and employment by field and on the pattern of student enrollments provide strong support for the proposition that the overall decline in the job market for college workers had very different effects on different disciplines. 
Table 8: Some Estimates of the Elasticity of Supply of Students to Diverse Fields

\author{
Elasticity of Supply With Respect to Salaries \\ Short Run \\ Long Run
}

\begin{tabular}{|c|c|c|c|}
\hline Law & & 0.95 & 2.79 \\
\hline \multirow[t]{3}{*}{ Physics, } & B.S. & 2.96 & 3.72 \\
\hline & M.S. & 0.93 & 2.82 \\
\hline & $\mathrm{Ph} . \mathrm{D}$. & .82 & 4.83 \\
\hline \multicolumn{2}{|l|}{ MBA } & 0.96 & 3.20 \\
\hline \multicolumn{2}{|c|}{ Engineering, B.S. } & 1.82 & 3.25 \\
\hline \multicolumn{2}{|c|}{ Biology, Ph.D. } & 1.05 & 2.77 \\
\hline
\end{tabular}

Source: Law, Freeman (1975a) table 2, line 4.

Physics, Freeman (1975b), table 4, lines 4-6

MBA, Freeman (1976a), p. 134, footnote 34

Engineering, Freeman (1976a), table 4, line 3

Biology, Freeman, unpublished report to National Academy of Sciences, summer 19753, table 15, line 5. 


\section{Summary of Section I}

Our examination of data on the changing job market for college-trained workers in the U.S. has supported the four propositions with which we began. There was a marked decline in the market for college workers which, while lessening at the end of the decade, did not restore traditional college advantages. There were sizeable differences in the experience of various fields in the period which greatly exacerbated differences between academic and research occupations and business occupations. There was a decline in the propensity to attend college, apparently due to changed economic incentives. There was differential enrollment and degree patterns among fields, apparently due to their different market conditions.

How did the higher educational system respond to those developments? What are the mechanisms by which colleges and universities react to labormarket induced changes in the behavior of young persons?

The remainder of this essay turns to these important questions. 


\section{Impact on Higher Education}

The way in which the 1970s turnaround in the college labor market affects higher education depends on the operation of the education market place. The purpose of this section is to examine this market and to analyse the adjustment made by higher educational institutions to the changes of the seventies. Because American higher education is highly decentralized, with over 3,000 colleges and universities competing for students, the sector can, with due allowance.for its distinct features, be fruitfully analysed in terms of the standard economic model of a competitive industry. The standard model directs attention to: the exit and entry of institutions, changes in prices of output, changes in profits and changes in prices paid factors specific to an industry, and changes in product mix, among other things. In this section I consider briefly certain distinct characteristics of higher education likely to affect these and related modes of adjustment and then examine the changes in the period under study.

\section{Distinctive features of academe}

The characteristics of higher education most likely to affect the operation of the market place are: nonprofit status of enterprises; the relatively small role played by the direct price, tuition, in the cost of education and in the income of colleges and universities; the extensive employment of highly educated workers "produced" within the system; institutional rules which limit variation in prices and certain forms of adjustment to. change.

1. The nonprofit status of colleges and universities can be expected to affect the response of higher education to market developments. While it is often asserted that nonprofit enterprises are less responsive to economic incentives than comparable profit-seeking firms, a simple model of nonprofit 
behavior can be developed to show that the contrary is more likely. Essentially this is because nonprofit enterprises lack a "buffer" in the form of profits, and thus have to adjust to changes in market conditions entirely through changes in resource usage whereas at least some of the adjustment of profit-seeking firms will take the form of changes in profits. If this argument (given in detail in Freeman, 1975, 1979) has at least some validity, we would expect considerable adjustment in the academic market to the seventies turnaround.

2. In contrast to most goods, whose price is the major component of cost to purchasers and the major receipt of income by sellers, the direct cost of higher education--tuition (and room and board)--constitutes only a modest share of the cost to student and of the income of institutions. On the student side, as Schultz argued years ago, the bulk of the cost of higher education consists of governmental funds and, in the case of private schools, endowment and gifts.

Table 9 documents these two important characteristics of the academic market place at the end of the 1970s. Panel A shows that in all institutions tuition constituted just $11 \%$ of the total cost of higher education (with room and board excluded) while tuition and room and board constituted $24 \%$ of the total cost. Even in private institutions, no more than $36 \%$ of the cost of higher education is attributed to the direct cost. Foregone income is the prime private cost in both cases. Panel B (based on a different but roughly consistent data source) shows that tuition constituted $40 \%$ of money spent on education of students but just $21 \%$ of total university income. In private institutions, however, most of student education expenditures was paid for by tuition, though tuition constituted only $37 \%$ of total private 
Table 9: Tuition and Room and Board as a Share of Cost and Expenditures in the Academic Market, 1978

A11 Institutions

A. As Component of Cost

1. Average Tuition and fees

2. Room and Board

3. Estimated foregone income

4. Total cost

a) without room \& board

b) with room and board

5. Ratio of (1) to (4a)

6. Ratio of $(1)+(2)$ to (4b)

B. Relative to Expenditures

7. Student Education Expenditures net of scholarship and fellowships (in thousands)

8. Tota1 Expenditures

45,971

9,855

.40

.21

Private

2793

1684

7877

9382

10,397

10,670

12,354

.11

.26

.36

9. Tuition and fees

24,824

7,352

10. Ratio of (9) to (7)

.24

11. Ratio of (9) to (8)

15.245

5,713

.78

.37

Source: line 1, 2, estimated as weighted average of private and public institutions with .78 weight on public and .22 on private, using data in Table 3.5, p. 110 of Condition of Education 1980 for weight and

Table 4.6, p. 158 for costs.

line 3 , estimated as $3 / 4$ ths of the total money income of year-round fulltime workers from Current Population Survey, Series P-60, \#123.

line 7, Condition of Education 1980, table 4.2, p. 150.

1ine 8, Condition of Education 1980, table 4.5, p. 156. 
institutional receipts.

The low share of direct cost in the private cost of higher education suggests that demand for higher education will be only modestly responsive to changes in tuition (and room and board) charges. Empirical analysis supports the implication. The seven studies cited by McPherson show an elasticity of enrollments to tuition of about 0.30, on average (Breneman and Finn, p. 181). The 0.3 estimate is, it should be noted, roughly consistent with estimates of responsiveness of enrollments to the salaries of college and high school graduates. Elasticities with respect to salaries are on the order of 2.00 ; given a tuition share in cost of .15, one would expect, if tuition was not a serious bottleneck due to problems of capital-financing, an elasticity of .30 , roughly the McPherson summary estimate. Such a highly inelastic demand for higher education has one obvious implication of policy-makers: colleges and universities as a group could raise receipts by increasing tuition charges. Because tuition constitutes only a modest share of receipts, however, even sizeable increases in tuition will not greatly raise total receipts. Individual institutions, however, are unlikely to exploit an inelastic demand curve, for as in other markets with many competing institutions, demand for the output of a given institution will be much more elastic than demand for the industry's output.

3. The production of the major input used in higher education, doctorate faculty, and the dependence of the demand for new faculty on changes in enrollment suggest application of capita1 goods accelerator models to the faculty market. Such models highlight the dynamic adjustment problems of an industry producing and employing a long-lived capital resource such as faculty and its potential for cyclic adjustment. 
For present purposes what is important is that a deceleration in the rate of growth of enrollments is likely to have a significant depressant effect on the demand for new PhDs which in turn can be expected to reduce demand for graduate training, with further negative effects on demand for faculty. Since PhD faculty are highly specialized--in some respects a resource specific to the industry--fluctuations in demand for faculty and thus in employment and salaries are likely to be sizeable in response to changes in demand for higher education.

4. Three institutional features of the academic market are also likely to affect the adjustment to changed economic conditions. The general goal for interfield "equity" in salaries--defined in terms of making cross-field differences as small as is feasible given the need to obtain faculty--tends to limit the ability of higher education to adjust rates of pay across fields to changes in market conditions. For example, from 1970 to 1975 , when the market for various disciplines changed immensely, the standard deviation of the $\log$ change of the salaries of academic doctorate scientists across fields was 0.089 while the comparable standard deviation across fields in industry was 0.385 (Freeman in Lewis, Becker, p. 73). The lack of variation suggests that the brunt of adjustments across disciplines will take the form of quantity rather than price changes.

A second important institutional constraint on higher education is the tenure system, which guarantees lifetime employment to faculty except for reasons of institutional financial crisis or incompetency. In periods of market contraction tenure can become a serious barrier to adjustment, as colleges and universities will not easily be able to keep on young workers of relatively high quality due to tenure committments. The institution of tenure places the onus of adjusting to economic changes on the new PhDs. 
The recent unionization of colleges and universities (in 1977 over 12 percent of campuses were organized, compared to no campuses in 1965, (Freeman in Lewis and Becker, p. 28)) may further constrain institutions due to egalitarian goals of most unions and may further force adjustments onto the young due to the genera1 pattern for unions to be especially responsive to the desires of older workers. To sum up, our analysis of the distinctive characteristics of higher education suggests that the response of academe to the 1970s turnaround in the job market will be marked by: sizeable changes in the quantity of resources used, with considerable impacts on the position of potential young faculty; adjustments in tuition and potentially large adjustments in the wages of faculty--the input specific to the sector.

\section{Adjustment in quantities}

Table 10 examines some of the quantitative responses of the higher educational system to the 1970 s turnaround. Line 1 records the number of institutions in the market: it shows a rapid growth in the number, particularly of 2 year institutions, from 1960 through 1974, followed by a notable levelling in the rate of growth. From 1960 to 1974, the number of higher educational institutions increased by $2.8 \%$ per annum compared to a compound growth of 1.0\% from 1974 to 1978. Because of the long lead time in construction, the number of new institutions entering the market did not begin levelling off until the latter part of the decade. A number of existing institutions were, however, forced to close their doors in the decade. According to the National Center for Education Statistics, 144, 1argely sma11 private collegcs. went out of business (Condition of Education, 1980, Table 4-15). A significant number of other institutions--30 universities, 803 4-year co11eges and 427 2-year institutions--reported current fund expenditures greater than current fund revenues, 
Table 10: Number of Institutions of Higher Education and of Faculty and Expenditures of Colleges and Universities

Number of Institutions

2-year

a11 other

Number of faculty(in thousands) as $\%$ total employment

Expenditures (in millions in constant \$)

as \% GNP

\begin{tabular}{|c|c|c|c|}
\hline 1960 & 1970 & 1974 & 1978 \\
\hline 2040 & 2855 & 3012 & 3134 \\
\hline 593 & 1061 & 1141 & 1193 \\
\hline 1447 & 1794 & 1871 & 1941 \\
\hline
\end{tabular}

$\begin{array}{rrrr}276 & 573 & 695 & 809 \\ 0.42 & 0.73 & 0.81 & 0.89\end{array}$

$6,523 \quad 18,500 \quad 21,470 \quad 24,071$

$.011 \quad .022 \quad .022 \quad 022$

Source:

Digest of Educational Statistics, 1980 (for 1978 figures) table 103 (\# of institutions), table 130 (revenue), table (faculty).

Statistical Abstract of the U.S. 1980

table 709 (GNP)

table 793 (CPI)

table 645 (total employment)

Condition of Education

table 3.7 , p. 114; table 3.10, p. 120; table 4.1, p. 148 
suggesting that more institutions are likely to go out of business in the coming decade (Condition of Education 1980, table 4-16).

Line 2 of Table 10 considers the impact of the 1970 s developments on employment of faculty. It shows a similar marked pattern of declining growth. From 1960 to 1970 , the number of faculty increased by $7.6 \%$ per annum; from 1970 to 1974 , by $4.9 \%$; from 1974 to 1978 , by $3.9 \%$. Relative to total employment the faculty share of the employed rose by 0.31 points from 1960 to 1970 , by .16 points in the next eight years.

Line 3 of the table examines the overall flow of resources to higher education in terms of constant 1978-9 dollars expenditures by institutions. It shows a levelling off in spending following the booming sixties, with the ratio of resources going to higher education to total national resources, as indicated by GNP, stabilizing at .022 in the 1970 s.

From the data in the table it appears that the levelling in demand for higher education produced a parallel levelling in resources going to the sector. With the number of PhDs increasing in the early part of the period, the slackened growth in faculty employment shown in Table 10 had a devastating effect on the position of new doctorates and on the age structure of the faculty. Table 11 shows a huge increase in the proportion of new PhDs "seeking appointments" but having no specific prospects over the period, with it should be noted significant differences across fields. Table 12 shows a notable "aging" in the faculty.

We conclude that there were significant quantitative adjustments to the seventies labor market changes, which took the form of slackened growth in numbers of institutions, faculty, and real resource usage. The quantitative adjustments fell most severely on young academics. 
Table 11: Percentage of Ph.D.'s Seeking Appointments but Having No Specific Job Prospects upon Receipt of Degree, Selected Disciplines

Discipline

\section{Al1}

Economics

Engineering

English

Psychology

Biological Sciences

Physical Sciences

Chemistry

\section{8}

6

3

7

4

6

$-$

$-$

5
1974

$\underline{1978}$

26

16

26

36

26

28

25

22
26

19

24

36

29

22

23

21

Source: Data for 1974 from Nationa1 Research Council, Summary Report of 1974 Doctorates, data for "all" 1968 from H.S. Astin "Career Profiles of Women Doctorates," in Academic Women on the Move, A. Rossi and A. Calderwood (eds.), p. 158; other data for 1968 from D. Breneman, Graduate School Adjustment to the 'New Depression' in Higher Education, (1975), Technical Report No. 3, Table 30, p. 46, with electrical engineering used for all engineers. Data for 1978 from National Research Council, Summary Report 1978, Doctorate Receipts from U.S. Universities, as sum of percent seeking employment or seeking postdoctorate study, table 2 , p. 28 .

Table 12: Changes in the Experience of Doctorate Science Faculty, 1968-1975

\begin{tabular}{lccc} 
& \multicolumn{3}{c}{$\begin{array}{c}\text { Percentage of Doctorate } \\
\text { Faculty With Seven or Less } \\
\text { Years Since Doctorate }\end{array}$} \\
\cline { 2 - 4 } & 1968 & 1974 & $\begin{array}{c}\text { Change } \\
1968-1974\end{array}$ \\
\hline All & 42.1 & 29.4 & -12.7 \\
Physics & 31.6 & 18.5 & -21.1 \\
Chemistry & 34.9 & 21.4 & -13.5 \\
Mathematics & 51.9 & 36.8 & -15.1 \\
Economics & 42.7 & 37.4 & -5.3 \\
Psychology & 43.8 & 38.7 & -5.6
\end{tabular}

Sources: U.S. National Science Foundation (1968: 10, table 2; $1974: 20$, table B-1; 1970: 189-190, table A44; 1975: 110 , tables B, B-25). 


\section{Adjustments in price}

In addition to the quantity adjustments to change in the academic market, there were noticeable changes in prices, both on the output and input sides of the market. As we saw in table 3, the constant dollar tuition and fees, and room and board, and also receipts by colleges and universities per student (net of scholarship support) declined after 1974 to levels in most cases below those at the beginning of the seventies decade. Relative to the family income of the parents of likely students, the drop is even more marked. Despite all of the hullabaloo about increasing costs of higher education, and difficulties of financing higher education the evidence shows the opposite: in a period of slackening demand, the price of the "output" fell, as would be expected in a reasonably functioning economic market. Complaints about the cost of education are probably due to the rise in cost relative to the falling economic advantage of college training.

Given the inelastic demand for higher education with respect to tuition, the reduced tuition changes presumably had only a modest effect on enrollments and thus tended to exacerbate rather than ameliorate the financial problems of higher education.

Table 13 turns to the price of the principal input specific to higher education, faculty. It shows a sizeable drop in the real compensation of faculty in the period, which translates into an even larger decline in the income of academics relative to other workers. Econometric calculations which relate salaries to enrollments, numbers of $\mathrm{PhDs}$ and the like suggest that much of the salary responsive reflects the impact of the numbers of PhDs seeking work relative to enrollments on the salaries. 
Table 13: Levels and Indexes of Faculty Salaries in Current and Constant (1967-68) Prices and the Consumer Price Index: 1967-68 to $1978-79$

\begin{tabular}{|c|c|c|c|c|c|}
\hline \multirow[b]{2}{*}{ Year } & \multicolumn{2}{|c|}{ Salaries in current prices } & \multicolumn{2}{|c|}{ Salaries in $1967-68$ prices } & \multirow{2}{*}{$\begin{array}{c}\text { Consumer } \\
\text { Price } \\
\text { Index }\end{array}$} \\
\hline & $\begin{array}{c}\text { Average } \\
\text { salany }\end{array}$ & Index & $\begin{array}{c}\text { Average } \\
\text { salary }\end{array}$ & Index & \\
\hline 1967.68 & $\$ 11,033$ & 100.0 & $\$ 11,033$ & 100.0 & 100.0 \\
\hline 1968.69 & 11,760 & 106.6 & 11.221 & 101.6 & 104.8 \\
\hline $1969-70$ & 12,637 & 114.5 & 11,293 & 102.4 & 111.1 \\
\hline 1970.71 & 13,284 & 120.4 & 11,373 & 103.1 & 116.8 \\
\hline $1971-72$ & $13,82 ?$ & 125.3 & 11,424 & 103.5 & 121.0 \\
\hline $19 / 2 \cdots .3$ & 14,552 & 131.9 & $\times 11.568$ & 104.8 & 125.8 \\
\hline 1973.14 & 15,459 & 140.1 & 11,276 & 102.2 & 137.1 \\
\hline $1974-75$ & 16.403 & 148.7 & 10,770 & 97.6 & 152.3 \\
\hline $1975-76$ & 17.450 & 158.2 & 10.699 & 97.0 & 163.1 \\
\hline $1976-71$ & 17.930 & 162.5 & 10,394 & 94.2 & 172.5 \\
\hline $1977-78$ & 18.897 & 171.3 & 10,265 & 93.0 & 184.1 \\
\hline $1978-79$ & 20,120 & 182.4 & 9,990 & 90.5 & 201.4 \\
\hline
\end{tabular}

SOURCE: American Associaticn of University Profossors, Academe: Bulletin of the AAUP. "An Era , i Continuing Decline: Annual Report on the Economic Status of the Profession, 1978-79". September 1373 
We conclude that the changed demand for higher education due to the changing labor market had sizeable price as well as quantity impacts.

\section{Other adjustments}

In addition to the classic price and quantity adjustments, colleges and universities sought to adjust to the slackened growth through marketing their product. In efforts to attract more "paying customers" many colleges took to advertising in newspapers and magazines, altering curriculum to appeal to adults, changing their curriculum. I described these efforts in The Overeducated American as follows:

"Cazenovia College in upstate New York, for instance, staked its future in such career-oriented areas as fashion design, and museum studies. "We'11 be involved in a long-term guessing game, trying to keep one jump ahead of the competition in guessing on the careers students will be prusuing. We're no longer in the position of telling students what the requirements are if they want a Cazenovie degree. Now we say: 'You tell us what you want, and we'll provide it." Other campuses, ranging from Brigham Young University (Utah) to Oklahoma City University to Massachusetts State College at Boston, began experimenting with new technologies of education. With federal support, these schools sought to redefine the goals of liberal education in terms of practical "marketable" skills, often patterned after the training that companies provide for executives. Even graduate schools and professional academic associations, particularly in history and English, began to consider "what we might teach master's and PhD's that will be valuable in business employment."

"Various other recruiting techniques were resorted to. Testing organizations, such as the College Entrance Examination Board, have sold names and addresses 
to college administrators who used them to solicit applicants. The Riverside campus of the University of California sent out 12,000 oversized decks of playing cards carrying campus facts on the back. Some colleges pressure prospective students with the type of hard sell once associated only with profit-making proprietary schools or business colleges--mailing out slick brochures, conducting telephone canvasses, and giving out such gimmicks as free T-shirts, bumper stickers, and so on. In some cases, public relations firms have been hired to take over the whole admissions operation, receiving substantial fees for recruiting. While apparently still rare, the tactic of bounty hunting--for which proprietary schools have earned much opprobrium-has appeared, with recruiters paid on the basis of the number of students "delivered". The job of admissions officers, particularly at weaker institutions, is no longer to weed out unsuitable applicants but to find warm bodies."

Since then, newspaper stories indicate that market efforts have if anything been expanded, referring to the torrent of direct-mail advertising, marketing and recruiting in college admissions. Among recent efforts are:

-preparation of elaborate filmstrips and television tapes; -college fairs, which function like trade shows;

-ads in newspapers and on radio;

-direct mailing, with the College Board selling names at 12 cents a name plus a $\$ 100$ fixed fee.

Indicative of the pattern, a new quarterly magazine, The Higher Education Marketing Journal, was instituted to provide information on how best to expand the market.

Despite all the marketing efforts, however, from the aggregate data they appear to have had at most a slight effect on demand for higher education. 
In the face of the economic reality of a declining return it's difficult to see how such efforts can have more than a marginal impact, though particular schools may of course benefit greatly.

\section{Summary of Section II}

In this section I have documented that in response to changes in the demands for higher education induced largely by the changing job market for college-trained workers the higher educational system has undergone several fundamental changes: resources employed have levelled of $f$, tuition and faculty salaries have fallen and efforts to expand the market have been made. These adjustments are comparable to those one might expect in other less idiosyncratic markets facing a change in product demand. 
III Conclusion

We have seen in preceeding sections that the college job market underwent extensive change in the 1970s and that those changes induced significant adjustment on the part of higher educational institutions. How likely is it that the market for college workers will remain depressed? What is the likely future for higher education? Can the way in which the higher educational! system responds to the changes in the market for its output be improved? This section addresses these questions.

First, with respect to the future of the job market for college graduates, my forecasts, and those of others, suggest that the market will indeed rebound toward the end of the 1980 s, due in large part to the reduced supply of new graduates resulting from a fall in the size of the youth population. While a smaller number of young persons will improve the economic stiuation of young graduates, it will have quite different effects on the economics of colleges and universities. As Cartter warned years ago, the 1980 s will be a period of substantial difficulty for colleges and universities and for academic faculty.

Because of the nature of the higher education market, there are reasons to believe that current and potential future adjustments to the changes in the market are far from optimal. First, as Breneman has noted, the "crazyquilt pattern of subsidies and costs" undoubtedly leads institutions, students, and governmental decision-makers to make policies which, while possibly rational in terms of the prices facing them, may very well be irrational in terms of the true costs to the economy. A recent Brookings publication Public Policy and Private Higher Education, has dealt with some of these issues, as they impact on the position of private colleges and institutions versus public colleges and institutions. A major cause of difficulty is governmental support of higher education through institutional aid rather than through aid to students. Institutional aid has the disadvantage of by-passing "purchasers" of education. Another problem is the institutional rules which 
places the burden of adjustment on younger PhDs and faculty. While colleges and universities are struggling to alter their employment practices to make adjustments more balanced by age, their success thus far has been modest. Third is the potential problem of excessive adjustments which overshoot the socially optimal level of enrollment and degrees. In the area of teacher education, where the decline in enrollments and degrees was immense in response to the poor market for school teachers, there are already reports of potential shortages in the future.

There are several alternative strategies or changes in modes of behavior which institutions of higher education may find beneficial in the next decade. Colleges and universities might ameliorate some of the problems of declining enrollments by linking liberal arts to vocational non-academic training, such as for union crafts, possibly through new degree offerings and operating procedures. By bringing together vocational nonacademic and liberal arts programs, the opportunity for blue-collar workers to undertake artistic and intellectual pursuits unrelated to their careers could be enhanced.

It may also be desirable to alter tuition charges to better reflect costs of different educational programs. For example, graduate programs are often subsidized by undergraudate tuitions, suggesting that graduate tuitions are too low. Such changes will tend to limit graduate enrollments, an effect that is not inconsistent with the anticipated lower demand for Ph.D.'s in many areas. If such price changes are not possible, it may be desirable to limit certain graduate programs even beyond the size determined by student choice. University policies should be such that educational prices or allocation decisions reflect true social costs, no matter who pays. 
A third possibility is to reduce the amount of time required for studies, by operating full-time during summer and vacation periods. The present 4 years needed for the bachelor's degree could be reduced, with considerable saving of forgone income to students and at no serious loss of educational quality. All else the same, the reduction in the time needed to obtain a degree, from 4 to 3 years, would cost a student four summers of work at low pay and gain him or her 1 year of work as a graduate at higher pay, raising the economic value of college training. While in the past the desire for summer leisure may have made a concentrated course of studies attractive to only a few, in the changed market more students are likely to find this option desirable. At the least, experiments in altering the time period of courses and the operations of academia should be made to learn the best ways to deal with the new market reality.

Because the American higher educational system is, despite its flaws, generally superior to that in the rest of the world, attention should be given to the possible expansion of foreign student enrollments, particularly from the newly rich oil countries and such developing countries as Brazil, Mexico, and others, whose human resource demands are likely to outstrip the capacity of domestic universities. Already, Venezuela has initiated a major program to "export" thousands of students to the United States for higher education. We have a comparative advantage in producing college training, it could be "sold" overseas, taking up some of the slack in domestic student enrol1ment.

Yet another possibility is for institutions to cut out certain curriculum and encourage greater student cross-enrol1ment at other schools which offer particular curriculum.

What is ultimately needed, however, for these or other adjustments to 
work best is some form of planning for the future market situation, presumably in conjunction with the governmental bodies that subsidise so much of higher education.

One hopes that, given the sizeable governmental funds involved, an effort will be made to develop economically rational plans for the next decade and an effort made to use those funds to induce economically rational decisions on the part of institutions. 


\section{References}

American Association of State Colleges, 1976. The Value of a College Education, Washington, D.C.

American Council on Education, The American Freshmen: National Norms for Fall 1974,1979

\section{- National Norms for Entering College Freshmen,}

\section{Fall 1966.}

Berger, Marc, "Effect of the Baby Boom on the Earnings Growth of Young Males," Paper presented at NBER Compensation Conference, 1980.

Carnoy, Martin and D. Marenbach. "The Return to Schooling in the United States, 1989-69." Journal of Human Resources, Vol. 10 (Summer 1975): pp. $312-31$.

Carter, A. 1971. "Scientific Manpower for 1970-1985," Science 172: 132-140. - 1976. Ph.D.'s and the Academic Labor Market (McGraw-Hill).

Chamberlain, Gary. "Omitted Variable Bias in Panel Data: Estimating the Returns to Schooling." Harvard Istitute of Economics Research, No. 618, May 1979.

Cohn, Elchanan. The Economics of Education, (Cambridge, Mass.: Ballinger) 1979. Dresch, Stephen P. "Demography, Technology and Higher Education: Toward a Formal Model of Educational Adaptation," Journal of Political Economy, 83, (June 1975).

Featherman, David. "Social Stratification in a Service Economy," University of Wisconsin, 1977.

Freeman, Richard B. The Labor Market for College-Trained Manpower, (Cambridge: Harvard University Press) 1971.

. "Overinvestment in College Training?" Journal of Human

Resources, 10 (Summer 1975): pp. 287-311. 


$$
-47-
$$

- "Lega1 Cobwebs: A Recursive Model of the Labor Market

for New Lawyers," Review of Economics and Statistics, 1975.

- "Supply and Salary Adjustments to the Changing Science

Manpower Market, American Economic Review, 1975.

- "Employment Opportunities in the Doctorate Manpower Market:

Biosciences and Psychology," report to the National Academy of Sciences, 1975.

- The Overeducation American. (New York: Academic Press)

1976.

- "A Cobweb Model of the Supply and Starting Salary of

New Engineers," Industrial Labor Relations Review, January, 1976.

- "The Decline in the Economic Rewards to College Education."

Review of Economics and Statistics 59 (February 1977).

Freeman, Richard B. and J. Herbert Holloman. "The Declining Value of College Going," Change (Sept. 1976): 24-31.

Griliches, Zvi. "Notes on the Role of Educaiton in Production Functions and

Growth Accounting," In Education, Income and Human Capita1, ed. W.L.

Hansen. (New York: N.B.E.R.).

Hansen, W.L. (ed.) Education, Income and Human Capital. (New York: N.B.E.R.) 1970.

, "Total and Private Rates of Return to Investment in Schooling," Journal of Political Economy 71 (April 1963): 128-40.

Jencks, Christopher, "Limited Degrees," comment in Working Papers for a New Society, (Summer 1976): 6-11.

Layard, P.R.G., and R.R. Fallon. "Capital-skill Complementarity; Income Distribution and Output Accounting," Journa1 of Political Economy, 83 (1975) 279-302.

Lecht, Leonard A. "Grading the College Diploma." The Conference Magazine 14, (Apri1 1999) 25-30. 
National Research Council, Summary Report of 1974 Doctorates.

National Research Council, Summary Report 1978, Doctorate Receipts from U.S. Universities.

National Science Foundation. Statistical Handbook of Science and Education, (NSF 60-13).

National Science Foundation. Two Years After the College Degree (NFS 63-26). Psacharopoulos, G., and K. Hinchcliffe, "Further Evidence on the Elasticity of Substitution Among Different Types of Educated Labor," Journal of Politica1 Economy, 80 (1972): 786-792.

Raisian, John, and Elaine Donovan, "Patterns of Real Wage Growth, 1967-1977: Who Has Prospered?" BLS Working Paper 104, November 1980.

Rumberger, Russel W. "The Economic Decline of College Graduates: Fact or Fallacy?" Journal of Human Resources 15 (Winter 1980) : 121-23.

Schultz, T.W. The Economic Value of Education. (New York: Columbia Univ. Press) 1963.

Schwartz, E1i and Robert Thornton. "Overinvestment in College Training?" Journal of Human Resources 15 (Winter 1980): 121-23.

Smith, James P. and Finis Welch. "The Overeducated American? A Review Article." Santa Monica, Calif.: Rand Corporation, 1978.

Science Manpower Commission. 1975. Manpower Comments. Solmon, Lewis C. "Capital Formation by Expenditures on Education in 1960," Journal of Political Economy 79 (November/December 1971).

Solmon, Lewis C. "The Dëfinition and Impact of College Quality," in Solmon, L. and Taubman, J. Does College Matter? (Academic Press).

Taubman, P. and T. Wales. Higher Education and Earnings, (New York: McGraw-Hill), 1974.

Witmer, David R. "Has the Golden Age of American Higher Education Come to an Abrupt End?" Journal of Human Resources 15 (Winter 1980) : 113-20. Witmer, David R. "Is the Value of College Going Really Declining," Change, Dec. 1976. 
U.S. Bureau of the Census, "School Enrollment," Current Population Reports, Series P-20; various editions, 1950-1979.

U.S. Census Bureau, U.S. Statistical Abstract 1980.

U.S. Census Bureau, Current Population Survey, Consumer Income Series P-60.

U.S. Bureau of Labor Statistics, Employment and Earnings, Jan. 1981.

U.S. Bureau of Labor Statistics, Employment of High School Graduates and Dropouts Special Labor Force Report, No. 168 (0ct. 1973).

U.S. Department of Commerce, Survey of Current Business, Nationa1 Income editions.

U.S. Department of Commerce, Trends in the Income of Families and Persons in the U.S., technical paper 3 .

U.S. Department of Labor, Educational Attainment of Workers March 1969 (Special Labor Force Report 125, 186, 240.

U.S. National Center for Education Statistics, Condition of Education 1979 , Condition of Education 1980

U.S. Office of Education, Projections of Educational Statistics to 1978-79, 1969 ed.

- Projections of Educational Statistics to 1984-85,

1975 ed.

- Projections of Educational Statistics to 1986-88.

U.S. Office of Education, Digest of Educational Statistics, 1972.

- Digest of Educational Statistics, 1975

, Digest of Educational Statistics, 1978

, Digest of Educational Statistics, 1980. 